\title{
LINGUISTIK HISTORIS KOMPARATIF DALAM REKONSTRUKSI BAHASA MANDAILING
}

\author{
RAHMAWATI \\ Universitas Prima Indonesia \\ rahmawati165@gmail.com
}

\begin{abstract}
ABSTRAK
Linguistik Komparatif Historis adalah cabang linguistik yang meneliti perkembangan bahasa dari satu waktu ke waktu yang lain, mengamati cara-cara perubahan bahasa, dan meneliti penyebab perubahan bahasa. tugas utama linguistik komparatif adalah menganalisis dan memberikan penjelasan tentang sifat perubahan bahasa. Secara umum, sifat bahasa yang pertama memiliki struktur (dimensi sinkronis) dan kedua bahasa selalu mengalami perubahan (dimensi diakronis). Linguistik Historis Komparatif dalam Bahasa Mandailing meliputi Rekonstruksi Morfem, netralisasi, reduplikasi, bentuk infleksi, rekonstruksi atas morfem dan penerapan rekonstruksi. Metode yang digunakan dalam penelitian ini adalah metode kualitatif. Tujuan penelitian ini adalah untuk mengetahui Linguistik Historis Komparatif Dalam Bahasa Mandailing. Alat yang digunakan dalam pengumpulan data adalah wawancara. Rekonstruksi dalam bahasa mandailing terdiri dari adanya alomorf, netralisasi, reduplikasi, dan infleksi. Rekonstruksi di atas morfem terjadinya rekonstruksi dari kata *aso dan *aen. Penerapan rekonstruksi terdapat contoh kata *babah dan *igung.
\end{abstract}

Kata kunci: Linguistik Komparatif Historis, Rekonstruksi, Bahasa Mandailing
A. PENDAHULUAN
atau Linguistik Bandingan Historis
Linguistik Historis Komparatif
adalah cabang ilmu linguistik yang
menelaah perkembangan bahasa dari

(Historical Comparative Linguistics) 
satu masa ke masa yang lain, mengamati cara bagaimana bahasabahasa mengalami perubahan, serta mengkaji sebab akibat dari perubahan bahasa. Menurut Robins (1975) Linguistik Komparatif termasuk dalam bidang kajian linguistik memiliki peran yang sangat penting dalam memberikan sumbangan berharga bagi pemahaman tentang hakekat kerja bahasa dan perkembangan (perubahan ) bahasabahasa di dunia. Sehubungan dengan hal itu, tugas utama dari linguistik komparatif adalah menganalisis dan memberikan penjelasan mengenai hakekat perubahan bahasa. Pada umumnya, hakekat bahasa itu (i) mempunyai struktur (dimensi sinkronis) dan (ii) bahasa selalu mengalami perubahan (dimensi diakronis).

Analisis bahasa secara sinkronis mempelajari hakikat bahasa bahwa bahasa-bahasa pada masa tertentu mempunyai struktur-struktur atau unsur-unsur bahasa yang disebut unsur fonologi, morfologi, sintaksis dan lain-lain. Sedangkan analisis bahasa secara diakronik yaitu menganalisis bahasa tidak hanya bagian-bagian bahasa yang mengalami perubahan tetapi juga perkembangan bahasa. Seperti yang diketahui bahwa bahasa-bahasa modern pada saat ini dulunya memiliki bahasa awal. Melalui analisis diakronik dicari hubungan antara bahasa-bahasa modern yang diduga berasal dari satu bahasa awal, yaitu dengan menentukan bentuk kognat (bentuk leksiko atau semantik dua bahasa sama dan artinya juga sama atau mirip) dan pseudokognat (bnetuk leksiko dua bahasa sama tapi artinya berbeda).

Metode kuantitatif juga dapat digunakan untuk menganalisis bahasa dari segi dimensi sinkronis dan diakronis, namun juga dapat digunakan dalam kajian linguistik tipology dan linguistik kontrasif . linguistik tipology dengan metode komparatif digunakan untuk mengkaji bahasa secara struktural berdasarkan dimensi sinkronis. Tujuannya untuk 
mengamati persamaan dan perbedaan tipe bahasa-bahasa di dunia berdasarkan kajian struktural berbagai tataran kebahasaan secara sinkronis. Sedangkan linguistik kontrasif dengan metode komparatif bertujuan untuk membandingkan bahasa-bahasa berdasarkan kajian struktur berbagai tataran kebahasaan secara sinkronis untuk tujuan didaktis tertentu dalam rangka mencapai keberhasilan pengajaran bahasa. Linguistik diakronik (Linguistik komparatif) untuk menentukan hubungan kekerabatan bahasa yaitu dengan menggunakan 3 metode yaitu metode kuantitatif dengan teknik leksikostatistik dan teknik grotokronologi, metode kualitatif dengan teknik rekonstruksi dan metode sosiolinguistik. Metode kualitatif dengan teknik grotokronologi digunakan untuk menentukan waktu pisah antara bahasa-bahasa yang berasal dari bahasa awal.

Penelitian linguistik historis komparatif (LHK) terhadap bahasa- bahasa Austronesia telah dilakukan oleh para ahli. Terbukti bahwa sejumlah karya tulis berupa disertasi yang menelaah sejarah bahasa-bahasa sekerabat di wilayah Indonesia Barat itu telah dilakukan oleh para ahli. Sejumlah karya tulis yang dimaksud antara lain karya Nothofer (1975), Sneddon (1978), Adelaar (1985), dan Usup 1986). Sejauh yang dapat diamati, untuk penelitian dalam bidang yang sama di Indonesia Timur baru tercatat tiga karya yang menelaah masalah tersebut secara mendalam, yaitu karya Stressmann (1928), Collin (1983), dan Fernandez (1988). Ketiga karya tersebut juga dalam wujud disertasi. Karya Stressmann dan karya Collin-Fenandez dihasilkan dalam selang masa lebih dari setengah abad.

B. KAJIAN TEORI

1. Rekonstruksi Dalam Rekonstruksi dalam: rekonstruksi yang dilakukan dalam 
satu bahasa untuk mendapatkan bentuk-bentuk tuanya. Dalam hal ini kita hanya menggunakan bahan-bahan dari satu bahasa saja, yaitu rekonstruksi atas alternasi morfofonemis atau atas alomorfalomorf suatu morfem.

Rekonstruksi ini bertujuan untuk memulihkan suatu bahasa pada tahap perkembangan tertentu pada masa lampau, dengan tidak mempergunakan bahan-bahan dari bahasa lain, melainkan hanya mempergunakan data dari bahasa itu sendiri. Rekonstruksi dalam dapat dilakukan karena beberapa kenyataan berikut dalam sebuah bahasa:

\section{Adanya alomorf}

Dalam bahasa Indonesia kita jumpai sejumlah bentuk kata seperti: berjalan, bermain, berdiri, belajar, berumah dan sebagainya. Dalam Linguistik Historis Komparatif kita mempersoalkan bagaiman bentuk dasarnya pada masa lampau. Apakah bentuknya itu ber-, atau be-, atau bel.

2. Netralisasi
Bahasa Jerman Modern memiliki sejumlah konsonan, di antaranya enam konsonan yang sering menimbulkan masalah, yakni /p/, /t/, /k/, /b/, /d/, dan /g/. keenamnya dapat muncul pada posisi awal dan tengah tetapi dalam posisi akhir hanya ada /p/, /t/ dan /k/. kata dasar dari kata benda dan kata sifat yang berakhir dengan sebuah stop akan memperlihatkan dua polanya berlainan bila ditambah akhiran infleksi:

(1) Ty.p - ty.pen 'tipe'

(2) Tawp - tawben 'tuli'

Dalam analisis deskriptif gejala ini juga dipersoalkan. Biasanya dikatakan bahwa konsonan /b/, /d/, dan /g/ secara deskriptif mengalami proses netralisasi pada posisi akhir, dan diganti dengan konsonan /p/, /t/. /k/. Kenyataan ini akan memberi peluang untuk menarik kesimpulan lebih jauh bahwa secara historis dalam bahasa Jerman yang lebih tua, konsonan /b/, /d/ dan /g/ harus muncul juga pada posisi akhir.

\section{Reduplikasi}


Reduplikasi merupakan peristiwa atau gejala lain dalam bahasa yang dapat dipergunakan untuk mengadakan rekonstruksi dalam. Misal dalam bahasa Sansekerta, Yunani dan Latin terdapat reduplikasi pada bentuk perfek kata kerja:

Sans : da - dau 'saya telah memberi' Yun : de - do - ka 'saya telah memberi'

Lat : de - di 'saya telah memberi'

4. Bentuk infleksi

Kasus mengenai hilangnya aspirata terdapat dalam bentuk infleksi, khususnya dalam infleksi nomen. Bentuk nominatif dari kata rambut dalam bahasa Yunani adalah thriks, sedangkan bentuk genitifnya adalah trikhos. Dalam kasus nominatif aspirata hilang dari konsonan /k/ karena ada penanda $/ \mathrm{s} /$.

Contoh:

Rekonstruksi dalam:Rekonstruksi bahasa jawa: bahasa jawa dialek Tengger, dialek banyumas, dialek solo, dialek jawa timuran dianalisis secara internal melalui rekonstruksi internal untuk menentukan protobahasa jawa.

\section{Rekonstruksi di atas Morfem}

Pengguna metode korespondensi fonemis, metode rekonstruksi fonemis, dan rekonstruksi morfemis mengandung asumsi bahwa terdapat relasi antar bahasa-bahasa yang dibandingkan itu. Dengan mengadakan rekonstruksi melalui korespondensi fonemis dapat disusun:

1. Fonem proto: yaitu fonem purba yang menurunkan satu fonem atau lebih dalam bahasabahasa sekarang

2. Morfem proto: yaitu morfem purba yang menurunkan satu morfem atau morfem-morfem dalam bahasa sekarang

3. Bahasa proto: yaiutu bahasa yang menurunkan beberapa bahasa baru 


\section{Penerapan Rekonstruksi}

Perkembangan dari suatu bahasa proto ke bahasa-bahasa kerabat yang sekarang ada, tidak terjadi sekaligus. Artinya dari suatu bahasa proto tidak secara serta-merta terjadi sejumlah bahasa kerabat. Proses perubahan selalu terjadi secara bertahap. Malahan dalam kenyataan ada kemungkinan bahwa dalam proses pencabangan itu ada bahasa yanh hilang dari pemakaian, entah karena penutur-penuturnya lenyap atau karena pendukung-pendukungnya sudah beralih menggunakan bahasa lain. Dalam teori yang di cetuskan sarjana bahasa abad XIX dikatakan bahwa dari suatu bahasa proto hanya diturunkan dua bahasa baru, tidak lebih dari itu. Sekarang kita member peluang lain bahwa dari suatu bahasa proto dapat diturunkan labih dari dua bahasa, tergantung dari faktor yang mendominasi terjadinya pencabangan itu. Bila suatu masyarakat bahasa yang homogen tiba-tiba dicerai-beraikan oleh bencana alam ke empat daerah yang secara geografis berpisah satu dari yang lain, maka secara logis dapat diterima bahwa akan timbul empat bahasa baru. Mengadakan rekonstruksi (fonemis dan morfemis) pada prinsipnya merupakan suatu usaha untuk menelusuri kembali jejak perpisahan itu.

\section{METODE PENELITIAN}

Metode penelitian itu merupakan cara ilmiah agar bisa memperoleh dan bisa mengumpulkan data-data dengan fungsi dan tujuan tertentu. Tujuan penelitian ini adalah untuk mengetahui Linguistik Historis Komparatif Dalam Bahasa Mandailing. Sesuai dengan tujuan penelitian diatas maka metode yang digunakan dalam penelitian ini adalah metode kualitatif.

Menurut Sugiyono (2010:15), menjelaskan bahwa Metode penelitian kualitatif merupakan metode penelitian yang berlandas-kan pada filsafat positivisme, digunakan untuk meneliti pada kondisi obyek 
yang alamiah, (sebagai lawannya adalah eksperimen) dimana peneliti adalah sebagai instrumen kunci, pengambilan sampel sumber data dilakukan secara purposivedan snowbaal, teknik pengumpulan dengan trianggulasi, analisis data bersifat induktif/kualitatif, dan hasil penelitian kualitatif lebih menekan makna dari pada generalisasi.

\section{HASIL}

DAN

\section{PEMBAHASAN}

Suatu tingkat rekonstruksi yang lain adalah rekonstruksi morfemis (antar bahasa kerabat), yang mencakup pula rekonstruksi atas alomorf-alomorf (rekonstruksi untuk menetapkan bentuk tua dalam satu bahasa).

\section{Adanya alomorf}

Dalam bahasa mandailingangkola kita jumpai sejumlah bentuk kata seperti mardalan, marlojong, manabusi, manambar, manyintak, manyiram dan sebagainya. Dalam analisa linguistik deskriptif dikatakan bahwa bentuk-bentuk tersebut diatas terdiri dari morfem terikat dan morfem dasar. Ada morfem dasar : dalan, lojong, tabusi, tampar, sintak, siram. Disamping itu ada morfem terikat : mar-, mana-, manyi-. Secara deskripsi dijelaskan bahwa bentuk-bentuk itu bervariasi karena lingkungan yang dimasukinya. Berdasarkan prosedur tertentu lalu ditetapkan bahwa ada satu morfem untuk masing-masing kelompok variasi bentuk diatas, sedangkan ketiga bentuk dari tiap satuan disebut alomorf.

Sesuai dengan prinsip rekonstruksi morfemis melalui rekonstruksi fonemis, kita dapat menentukan bagaimana bentuk morfem-morfem terikat. Berdasarkan prinsip kesederhanaan, serta melihat distribusi tiap alomorf, maka dapat disimpulkan bahwa bentuk pr oto alomorf diatas adalah :*/mar/.

\section{Netralisasi}

beberapa gejala nusantara dapat memperkuat hipotesa ini yaitu adanya posisi $* / \mathrm{z} /$ pada posisi akhir dalam kata bozoka, ijazah, inza yang 
diucakapkan dengan */s/ : /basoka/

/jasah//insa/. Kata tersebut pertama

disebarluaskan dengan tulisan bukan melalui bahasa lisan.

\section{Reduplikasi}

Reduplikasi merupakan peristiwa atau gejala lain dalam bahasa yang dapat dipergunakan untuk mengadakan rekonstruksi dalam. Dalam bahasa-bahasa Austronesia juga terdapat peristiwa bahasa yang sama. Dalam bahasa ini terdapat juga bentukbentuk reduplikasi pada suku awal seperti kata: sanjongkal-sasanjongkal, saotik-sasaotik, sadari-sasadari.

Dalam bahasa mandailing reduplikasi ini mengalami pengulangan pada suku kata pertama, misalkan pada kata: sanjongkal, saotik, sadari sebagai bentuk dasar mengalami reduplikasi dengan pengulangan suku kata $-s a$. Bentuk asli dari perulangan pasangan katakata diatas adalah:

Sanjongkal : sanjongkalsanjongkal : sasanjongkal Saotik : saotik-saotik :sasaotik
Sadari $\quad$ :sadari-sadari

$\therefore$ sasadari

\section{Bentuk Infleksi}

Bentuk infleksi tidak terdapat dalam bahasa mandailing.

\section{Rekonstruksi di atas Morfem}

Dalam bahasa mandailingangkola di temukan pada kata *aso 'kenapa' merupakan rekonstruksi dari kata mandailing-angkola boanso, anso, aso. Pada pasangan kata tersebut yang pertama adanya penambahan partikel /bo dan $n /$ kedua menghilangkan partikel /bo/ menjadi anso dan yang terakhir menghilangkan partikel $/ n /$.

Kata *aen 'karena' merupakan rekonstruksi dari kata mandailingangkola binaenni, abenni, benni. Pada pasangan kata tersebut yang pertama adanya penambahan partikel /bin/ kedua penambahan partikel /b/ dan yang ketiga menghilangkan partikel /a/. 


\section{Penerapan Rekonstruksi}

Untuk

mengadakan

rekonstruksi menelusuri gerak perpisahan kita mengambil contoh berikut. Kata mulut dalam beberapa bahasa nusantara adalah sebagai berikut: Mandailing: baba, batak toba: baba, batak karo: babah, batak simalungun: babah, batak pakpak: babah, bahasa jawa: cangkem, dan bahasa padang: muluik.

Langkah pertama yang harus dilakukan adalah mengadakan pengelompokkan bentuk-bentuk yang identik, yaitu:

1. Baba terdapat dalam 2 bahasa

2. Babah terdapat dalam 3 bahasa

3. Cangkem terdapat dalam 1 bahasa

4. Muluik terdapat dalam 1 bahasa

Dari data tersebut diatas terdapat sejumlah korespondensi fonemis antara $/ b, c, m /$ antara $/ a, n g$, $u /$, antara / $k, l /$, antara /e, $i, /$. Bila kita mengikuti prosedur rekonstruksi fonemis, maka dari bentuk pantulan ini langsung di temukan bentuk protonya. Namun berdasarkan prinsip pencabangan yang bertahap, akan diikiuti prosedur yang lain yaitu mengadakan rekonstruksi yang bertahap pula. Dari tingkat kemiripan struktur fonemisnya pada tahap pertama diadakan pengelompokkan bagi pasangan-pasangan yang mirip. Dengan demikian proses rekonstruksinya adalah sebagai berikut:

Baba dan babah merupakan pantulan dari kata babah

Cangkem dan muluik tidak ditemukan hubungan kekerabatan.

Hasil dari seluruh rekonstruksi yang dilakukan diatas menyatakan bahwa bentuk proto yang menurunkan ke tujuh bentuk kerabat ini adalah *babah.

Untuk mengadakan rekonstruksi menelusuri gerak perpisahan kita mengambil contoh berikut. Kata hidung dalam beberapa bahasa nusantara adalah sebagai berikut: Mandailing: igung, batak toba: igung, batak karo: igung, batak simalungun: igung, batak pakpak: egung, bahasa jawa: irung, dan bahasa padang: hiduang.

\section{Langkah pertama yang harus}


dilakukan adalah mengadakan pengelompokkan bentuk-bentuk yang identik, yaitu:

1. Igung terdapat dalam 4 bahasa

2. Egung terdapat dalam 1 bahasa

3. Irung terdapat dalam 1 bahasa

4. Iduang terdapat dalam 1 bahasa

Dari data tersebut diatas terdapat sejumlah korespondensi fonemis antara $/ i, e, /$, antara $/ g, r, d /$, antara / $u, u a /$, antara /ng, $n g, n g, n g /$. Bila kita mengikuti prosedur rekonstruksi fonemis, maka dari bentuk pantulan ini langsung di temukan bentuk protonya. Namun berdasarkan prinsip pencabangan yang bertahap, akan diikiuti prosedur yang lain yaitu mengadakan rekonstruksi yang bertahap pula. Dari tingkat kemiripan struktur fonemisnya pada tahap pertama diadakan pengelompokkan bagi pasanganpasangan yang mirip. Dengan demikian proses rekonstruksinya adalah sebagai berikut:

Igung dan egung merupakan pantulan dari kata igung Irung dan iduang diturunkan dari kata igung.

Hasil dari seluruh rekonstruksi yang dilakukan diatas menyatakan bahwa bentuk proto yang menurunkan ke tujuh bentuk kerabat ini adalah *igung.

\section{E. KESIMPULAN}

Linguistik Historis Komperatif adalah cabang ilmu linguistik yang menelaah perkembangan bahasa dari satu masa ke masa yang lain, mengamati cara bagaimana bahasabahasa mengalami perubahan, serta mengkaji sebab akibat dari perubahan bahasa.

Rekonstruksi dalam terdiri dari adanya alomorf, netralisasi, reduplikasi, dan infleksi. Rekonstruksi di atas morfem terjadinya rekonstruksi dari kata *aso dan *aen. Penerapan rekonstruksi terdapat contoh kata *babah dan *igung.

\section{DAFTAR PUSTAKA}

Chaer, Abdul, 1998. Tata Bahasa Praktis Bahasa Indonesia. Jakarta: Penerbit PT Rineka 
Cipta.

Keraf, Gorys. 1990. Linguistik

Bandingan Tipologis. Jakarta:

Gramedia.

Robins, R.H.. 1190. A Short History of

Linguistics. London dan Newyork:

Longman.
Sampson, Geoffrey. 1980. Schools of Linguistics. Stanford and California: Stanford University Press.

Suhardi. 2013. Pengantar Linguistik Umum. Yogyakarta: Ar-Ruzz Media. 